\title{
Penerapan Metode Pembelajaran Kooperatif Berbasis Kasus Terhadap Efektivitas Pembelajaran Mahasiswa Akuntansi Universitas Kristen Maranatha
}

\author{
Aurora Angela \\ Fakultas Ekonomi Program Studi Akuntansi-Univ.Kristen Maranatha \\ (Jl. Prof. Drg. Suria Sumantri No. 65, Bandung) \\ aurora.ang31@yahoo.com \\ Lauw Tjun Tjun \\ Fakultas Ekonomi Program Studi Akuntansi-Univ.Kristen Maranatha \\ (Jl. Prof. Drg. Suria Sumantri No. 65, Bandung) \\ lauwtjuntjun@gmail.com \\ Sunardi Indrawan \\ Fakultas Ekonomi Program Studi Akuntansi-Univ.Kristen Maranatha \\ (Jl. Prof. Drg. Suria Sumantri No. 65, Bandung) \\ sunardi_indrawan@yahoo.com \\ Ray Krismawan \\ Fakultas Ekonomi Program Studi Akuntansi-Univ.Kristen Maranatha \\ (Jl. Prof. Drg. Suria Sumantri No. 65, Bandung) \\ reykick2@gmail.com
}

\begin{abstract}
The quality of learning is not only limited to the effectiveness of knowledge transfer, but also on the development of basic attitudes, such as critical scientific academic attitudes and continual willingness to seek the truth. In this case, educators are required not only to transfer of knowledge, but more than that also acts as an enlightenment agent. Therefore, this study aims to obtain empirical evidence of the influence of application of case-based cooperative learning methods to the learning effectiveness of the accounting students on Maranatha Christian University.The technique used to test the hypothesis is Simple Linear Regression Analysis, which used to know the influence of the application of case-based cooperative learning method to the effectiveness of student learning. Respondents in this study are accounting students of Maranatha Christian University.

The result of this study shows that case-based cooperative learning method positively affects the learning effectiveness of the accounting students on Maranatha Christian University.
\end{abstract}

Keywords: Case-Based Cooperative Learning Method, Learning Effectiveness.

\section{Pendahuluan}

Upaya meningkatkan kualitas dan efektifitas pembelajaran di berbagai Universitas terus dilakukan. Tersedianya sumberdaya yang baik dan memadai di perguruan tinggi merupakan persyaratan yang diperlukan, tetapi tidaklah mencukupi. Ketersediaan itu selalu masih harus dikaitkan dengan pengaturannya agar dapat menghasilkan kinerja yang lebih baik. Kualitas pembelajaran tidak hanya terbatas pada efektifitas transfer pengetahuan namun juga pada perkembangan sikap dasar, seperti sikap kritis akademis ilmiah dan kesediaan terus mencari kebenaran (Yumarma, 2006).
Pendidik dituntut tidak sekedar sebagai pentransfer ilmu, namun lebih dari itu juga berperan sebagai agen pencerahan. Kebanyakan proses pembelajaran dipraktikkan sekarang ini berbentuk ceramah (lecturing). Pada saat mengikuti kuliah atau mendengarkan ceramah, mahasiswa sebatas memahami sambil membuat catatan. Dosen menjadi pusat peran dalam pencapaian hasil pembelajaran dan seakan-akan menjadi satu-satunya sumber ilmu.

Dalam hal ini pola pembelajaran dosen aktif dengan mahasiswa pasif ini mempunyai tingkat efektivitas pembelajaran yang rendah. Umumnya efektivitas pembelajaran mahasiswa terjadi pada saatsaat akhir mendekati ujian. Hal ini juga tercermin 
dalam keseharian perkuliahan sebagian besar mahasiswa di berbagai Universitas. Pembelajaran yang berfokus pada pemahaman materi saja membuat mahasiswa tidak memiliki gambaran penerapan materi pada dunia bisnis maupun dunia professional yang nantinya akan dijalani. Sehubungan dengan hal tersebut perlu adanya pembaruan metode pembelajaran, dari yang semula tutorial menjadi metode pembelajaran yang memberdayakan mahasiswa, karena sesungguhnya perguruan tinggi adalah tempat dimana mahasiswa belajar dan mengembangkan diri, bukan tempat dosen mengajar saja.

Higher Education Long Term Strategy (HELTS) 2003-2010 yang dikeluarkan Ditjen Dikti bulan April 2003 memberi amanah yang salah satunya adalah penerapan prinsip Student-Centered Learning (SCL) dalam proses pembelajaran. Terdapat beragam metode pembelajaran untuk SCL dan dua di antaranya adalah Case-Based Learning dan Cooperative Learning. (Mutmainah, 2008). Alasan utama CaseBased Learning adalah: (1) pembelajaran memerlukan adanya ilustrasi kasus nyata dalam empat penerapan ilmu yang diperoleh dari kuliah dan buku teks; (2) pengajaran berbasis kuliah saja seringkali membuat mahasiswa menjadi pasif; (3) proses belajar yang efektif adalah proses yang melibatkan refleksi (double loop learning). Pembelajaran berbasis kasus adalah proses pembelajaran yang memungkinkan terjadi double-loop learning. Dalam bidang pendidikan ada sebuah peribahasa yang berbunyi "tell me and I will forget, show me and I will remember, involve me and I will understand." Diharapkan dengan melibatkan mahasiswa dalam case-based learning, mahasiswa memiliki pemahaman yang lebih baik dibanding bila hanya sebatas menerima teori saja (Mutmainah, 2008).

Sistem pembelajaran cooperative learning diperkenalkan pertama kali oleh Robert Slavin pada tahun 1987. Sejak diperkenalkan metode ini telah sukses diterapkan dan konsisten dan direkomendasikan oleh berbagai organisasi pendidikan terkemuka di dunia. Cooperative learning secara umum diartikan sebagai suatu kelompok kecil yang terdiri dari mahasiswa yang heterogen, yang bekerja sama untuk saling membantu satu sama lain dalam belajar. Metode pembelajaran ini merupakan alternatif yang ditawarkan untuk mengatasi kelemahan yang terdapat pada model pembelajaran tradisional (Slavin, 2008). Sejumlah penelitian menunjukkan bahwa selain dapat meningkatkan prestasi belajar mahasiswa, cooperative learning juga dapat meningkatkan kemampuan noncognitive seperti self-esteem, perilaku dan karakter, toleransi serta dukungan bagi mahasiswa lain.

\section{Kerangka Pemikiran dan Hipotesis}

Kebanyakan proses pembelajaran dipraktikkan sekarang ini berbentuk ceramah (lecturing). Pada saat mengikuti kuliah atau mendengarkan ceramah, mahasiswa sebatas memahami sambil membuat catatan. Dalam hal ini pola pembelajaran dosen aktif dengan mahasiswa pasif ini mempunyai tingkat efektivitas pembelajaran yang rendah. Sehubungan dengan permasalahan tersebut, metode pengajaran yang diusulkan untuk diterapkan pada kegiatan pembelajaran di berbagai universitas adalah casebased learning dan cooperative learning.

Sejumlah penelitian menunjukkan bahwa dengan metode pembelajaran cooperative learning selain dapat meningkatkan prestasi belajar mahasiswa, cooperative learning juga dapat meningkatkan kemampuan noncognitive seperti self-esteem, perilaku dan karakter, toleransi serta dukungan bagi mahasiswa lain. Dan dengan melibatkan mahasiswa dalam case-based learning, diharapkan mahasiswa memiliki pemahaman yang lebih baik terhadap materi pembelajaran dan dunia praktik.

Berikut merupakan model penelitian dalam penelitian ini:

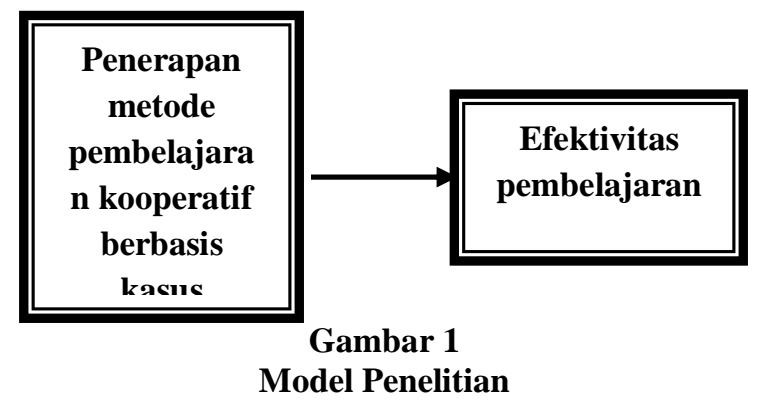

\section{Pengembangan Hipotesis}

Berdasarkan kerangka pemikiran, dapat dirumuskan hipotesis penelitian sebagai berikut:

H1: $\quad$ Penerapan metode pembelajaran kooperatif

berbasis kasus berpengaruh terhadap

efektivitas pembelajaran mahasiswa

akuntansi Universitas Kristen

Maranatha.

\section{Kerangka Teoritis}

\section{Pembelajaran Berpusat pada Mahasiswa (Student Centered Learning)}

Masih cukup sulit untuk mengubah perilaku mahasiswa yang hanya dengan hadir, mendengar, dan mencatat. Idealnya proses perkuliahan yang baik selalu melibatkan proses diskusi dan tanya jawab di dalamnya. Untuk mencapai proses tersebut, sebelum perkuliahan, mahasiswa harus siap dengan topik yang akan dibahas, sehingga mereka tidak memanfaatkan 
kelas sebagai tempat untuk duduk, mendengar, dan mencatat, tetapi untuk mengajukan pertanyaan dan berdiskusi tentang topik bahasan. Proses seperti ini merupakan proses yang ideal diterapkan dalam perkuliahan. Proses perkuliahan yang bertumpu pada kemandirian siswa dalam mencari ilmu atau student centered learning (Slavin, 2008).

Dengan model pembelajaran student centered learning mahasiswa lebih berperan aktif dengan membaca, mendengarkan, menulis dan berbicara. Melalui model ini juga, dosen dituntut untuk terus-menerus memperbarui pengetahuan mereka. Proses belajar seperti ini sangat membantu untuk membina kekuatan nalar dan analisis yang kuat. Jadi melalui proses pembelajaran ini, dosen hanya berfungsi untuk berbagi pengalaman tentang materi yang dibahas untuk siswa. Menurut Afiatin (2009) ada lima faktor yang penting diperhatikan dalam prinsip psikologis pembelajaran berpusat pada mahasiswa, yaitu:

1. Faktor Metakognitif dan kognitif yang menggambarkan bagaimana siswa berpikir dan mengingat, serta penggambaran faktor yang terlibat dalam proses pembentukan makna informasi dan pengalaman;

2. Faktor Afektif yang menggambarkan bagaimana keyakinan, emosi, dan motivasi mempengaruhi cara seseorang menerima situasi pembelajaran, berapa banyak orang belajar, dan usaha yang mereka lakukan untuk terus mengikuti pembelajaran.

3. Faktor Perkembangan yang menggambarkan bahwa kondisi fisik, intelektual, emosional, dan sosial dipengaruhi oleh faktor genetik yang unik dan faktor lingkungan;

4. Faktor Pribadi dan sosial yang menggambarkan bagaimana orang lain berperan dalam proses pembelajaran dan caracara orang belajar dalam kelompok. Prinsip ini mencerminkan bahwa dalam interaksi sosial, orang akan saling belajar dan dapat saling menolong melalui saling berbagi perspektif individual;

5. Faktor Perbedaan Individual yang menggambarkan bagaimana latar belakang individu yang unik dan kapasitas masing masing berpengaruh dalam pembelajaran.

\section{Pembelajaran Kooperatif (Cooperative Learning)}

Menurut Wikipedia, pembelajaran kooperatif atau cooperative learning merupakan istilah umum untuk sekumpulan strategi pengajaran yang dirancang untuk mendidik kerja sama kelompok dan interaksi antar siswa. Tujuan pembelajaran kooperatif setidaktidaknya meliputi tiga tujuan pembelajaran, yaitu hasil belajar akademik, penerimaan terhadap keragaman, dan pengembangan keterampilan sosial.

Berbagai riset tentang cooperative learning menunjukkan hasil yang konsisten bahwa cooperative learning akan meningkatkan prestasi, hubungan interpersonal yang lebih positif dan kepercayaan diri yang lebih tinggi dibanding upaya kompetitif atau individualistis. Phipps et al. (2001) menyatakan bahwa pendekatan ini meningkatkan motivasi untuk belajar, memori pengetahuan, kedalaman pemahaman dan apresiasi subyek yang diajar. Praktik cooperative learning mengarahkan mahasiswa pada pencapaian prestasi yang lebih tinggi, lebih efisien dan efektifnya proses dan pertukaran informasi, meningkatkan produktivitas, hubungan yang positif di antara mahasiswa, dan membentuk saling percaya antar teman, dibandingkan dengan pengalaman pembelajaran kompetitif dan/atau individualistis (Potthast, 1999).

Mutmainah (2008) dalam penelitiannya menemukan hal yang sama yaitu pembelajaran kooperatif akan meningkatkan prestasi, hubungan interpersonal yang lebih positif dan self-esteem yang lebih tinggi dibanding upaya kompetitif atau individualistis. Pembelajaran kooperatif diukur dengan instrumen yang dikembangkan oleh Mutmainah dengan indikator variabel yaitu:

1. Tingkat saling ketergantungan secara positif. Setiap anggota tim saling membutuhkan untuk sukses. Sekecil apapun perannya, sebuah tim membutuhkan saling ketergantungan dengan individu lain.

2. Interaksi langsung (tatap muka). Memberikan kesempatan kepada siswa secara individual untuk saling membantu dalam memecahkan masalah, memberikan umpan balik yang diperlukan antar anggota untuk semua individu, dan mewujudkan rasa hormat, perhatian, dan dorongan di antara individu-individu sehingga mereka termotivasi untuk terus bekerja pada tugas yang dihadapi.

3. Tanggung jawab individu dan kelompok. Tujuan belajar bersama adalah untuk menguatkan kemampuan akademik mahasiswa, sehingga kontribusi tiap individu harus adil.

4. Keterampilan interpersonal dan kelompok kecil. Keterampilan kerjasama tim sangat penting untuk mencapai tujuan pembelajaran. Cara meningkatkannya adalah dengan cara mengajarkan kepemimpinan, pengambilan keputusan, membangun kepercayaan, komunikasi, dan keterampilan manajemen konflik.

5. Pemilihan anggota kelompok. Dosen perlu mengatur struktur kelompok agar tidak ada individu yang tidak berkontribusi.

6. Proses kerja kelompok. Proses kerja kelompok memberikan umpan balik kepada anggota kelompok tentang partisipasi mereka, memberikan kesempatan untuk meningkatkan keterampilan pembelajaran kolaboratif anggota, membantu untuk mempertahankan hubungan kerja yang baik antar anggota, dan menyediakan sarana untuk merayakan keberhasilan kelompok. 
7. Evaluasi kelompok. Dosen mengamati setiap kelompok dan memberikan umpan balik yang baik untuk kelompok.

\section{Pembelajaran Berbasis Kasus (Case-Based Learning)}

Pembelajaran berbasis kasus melibatkan kondisi interaktif, dimana melatih mahasiswa menghadapi situasi realistic dan membutuhkan penalaraan. Ketika mahasiswa mempertimbangkan adanya suatu permasalahan berdasarkan perspektifnya, mereka diarahkan untuk memecahkan pertanyaan yang tidak memiliki jawaban tunggal.

Menurut Handoko (2005) suatu kasus disebut sebagai kasus baik bila memiliki karakteristik sebagai berikut:

1. Berorientasi keputusan: kasus menggambarkan situasi manajerial yang mana suatu keputusan harus dibuat (segera), tetapi tidak mengungkap hasilnya.

2. Partisipasi: kasus ditulis dengan cara yang dapat mendorong partisipasi aktif mahasiswa dalam menganalisis situasi. Ini berbeda dengan cerita (stories) pasif yang hanya melaporkan berbagai peristiwa atau kejadian seperti apa adanya, tetapi tidak mendorong partisipasi.

3. Pengembangan diskusi: material kasus ditulis untuk memunculkan beragam pandangan dan analisis yang dikembangkan oleh para mahasiswa.

4. Substantif: kasus terdiri atas bagian utama yang membahas isu dan informasi lain.

5. Pertanyaan: kasus biasanya tidak memberikan pertanyaan, karena pemahaman atas apa yang seharusnya ditanya merupakan bagian penting analisis kasus.

Menurut Mutmainah (2008) dapat disimpulkan manfaat metode kasus diterapkan sebagai metode pembelajaran adalah:

1. Meningkatkan kemampuan memecahkan masalah. Kasus memberi kesempatan kepada mahasiswa pengalaman dalam menghadapi berbagai masalah di organisasi. Kasus memfasilitasi pengembangan kemampuan untuk menilai suatu masalah

2. Meningkatkan pemahaman materi. Kasus menyajikan berbagai isu nyata yang relevan. Kasus menyajikan ilustrasi teori dan materi kuliah. Realisme kasus memberikan insentif bagi mahasiswa untuk lebih terlibat dan termotivasi dalam mempelajari material pembelajaran.

3. Kemampuan menginterpretasikan sesuatu. Kasus mengembangkan kapabilitas mahasiswa untuk mengintegrasikan berbagai konsep material pembelajaran untuk memecahkan suatu masalah.
4. Kontribusi dalam pembelajaran. Metode kasus memberi kesempatan mendapatkan pengalaman dalam mempresentasikan gagasan kepada orang lain dan kasus memberikan pengalaman yang dapat diterapkan pada situasi pekerjaan.

\section{Efektivitas Pembelajaran}

Efektivitas program pembelajaran berkaitan dengan pencapaian masalah tujuan pembelajaran, fungsi dari unsur-unsur pembelajaran, serta tingkat kepuasan dari individu terlibat dalam pembelajaran. Pembelajaran dikatakan efektif jika proses pembelajaran dari setiap elemen berfungsi sebagai keseluruhan, peserta merasa senang, puas dengan hasil pembelajaran, membawa kesan, sarana/fasilitas memadai, bahan yang memadai sesuai dan metode, dan guru/dosen yang profesional. Tinjauan utama efektivitas pembelajaran adalah outputnya, yaitu kompetensi mahasiswa. Efektivitas pembelajaran dapat dicapai jika desain dalam penyusunan, pelaksanaan, dan evaluasi dapat dilakukan sesuai dengan prosedur dan sesuai dengan fungsinya masing-masing (Muhidin, 2009).

Suardana (2006) mengukur efektifitas pembelajaran dengan indikator sebagai berikut:

1. Peningkatan kualitas kemampuan memecahkan masalah. Pemecahan masalah yang dilakukan oleh sebagian besar mahasiswa sudah terstruktur dimulai dari visualisasi masalah, deskripsi konsep, rencana penyelesaian masalah, melaksanakan penyelesaian masalah, dan mengevaluasi kembali.

2. Peningkatan aktifitas mahasiswa dalam pembelajaran. Bebarapa aspek yang sangat menonjol dan berlangsung dengan baik adalah kerjasama kelompok, interaksi antar mahasiswa dan antara mahasiswa dan dosen, mahasiswa yang bertanya dan menjawab dalam diskusi kelas, mengalami peningkatan yang berarti dari sebelumnya.

3. Peningkatan hasil belajar mahasiswa. Hasil belajar mahasiswa tergolong baik dan lebih tinggi daripada sebelumnya.

4. Respon positif terhadap proses pembelajaran. Semua anggota kelompok memperoleh manfaat dari kegiatan belajar tersebut. Sebagian besar mahasiswa mengharapkan agar model pembelajaran ini terus dilanjutkan dan dikembangkan.

\section{Metode Penelitian}

\section{Desain Penelitian}

Penelitian ini merupakan penelitian deskriptif analisis. Penelitian ini mencoba mengidentifikasi penerapan metode pembelajaran kooperatif berbasis kasus terhadap efektifitas pembelajaran mahasiswa akuntansi Universitas Kristen Maranatha. 


\section{Subjek/ Objek Penelitian}

Objek dalam penelitian ini terdiri dari dua variabel, yaitu metode pembelajaran kooperatif berbasis kasus dan efektifitas pembelajaran mahasiswa. Sehubungan dengan objek penelitian tersebut, maka tempat yang dijadikan sebagai subjek dalam penelitian ini adalah Universitas Kristen Maranatha.

\section{Operasionalisasi Variabel}

Tabel 1

Operasionalisasi Variabel Penelitian

\begin{tabular}{|c|c|c|c|}
\hline Variabel & Dimensi & Indikator & Skala \\
\hline & & * Tingkat saling ketergantungan secara positif & Interval \\
\hline & Pembelajaran & * Interaksi langsung/ tatap muka dalam kelompok & Interval \\
\hline & Kooperatif & * Tanggungjawab individu dan kelompok & Interval \\
\hline Metode & & * Keterampilan interpersonal dan kelompok & Interval \\
\hline Pembelajaran & & * Pemilihan anggota kelompok & Interval \\
\hline Kooperatif & & * Proses kerja kelompok & Interval \\
\hline Berbasis Kasus & & * Evaluasi kelompok & Interval \\
\hline \multicolumn{4}{|l|}{ (X) } \\
\hline & Pembelajaran & * Tingkat kemampuan memecahkan masalah & Interval \\
\hline & Berbasis Kasus & * Tingkat pemahaman materi & Interval \\
\hline & & * Kemampuan menginterpretasikan sesuatu & Interval \\
\hline & & * Kontribusi dalam pembelajaran & Interval \\
\hline \multicolumn{4}{|c|}{ Sumber : Siti Mutmainah (2008) } \\
\hline Efektifitas & Hasil & * Peningkatan kualitas kemampuan memecahkan masalah & Interval \\
\hline Pembelajaran & Pembelajaran & * Peningkatan aktifitas mahasiswa dalam pembelajaran & Interval \\
\hline \multirow[t]{2}{*}{ (Y) } & Mahasiswa & * Peningkatan hasil belajar mahasiswa & Interval \\
\hline & & * Respon positif terhadap proses pembelajaran & Interval \\
\hline Imber : I Ny & & & \\
\hline
\end{tabular}

\section{Sampel Penelitian}

Sampel dalam penelitian ini adalah 100 orang mahasiswa akuntansi Universitas Kristen Maranatha. Unit observasi yang digunakan adalah mahasiswa yang masih aktif berkuliah. Pengambilan sampel menggunakan teknik purposive sampling.

\section{Teknik pengumpulan Data}

Secara umum digunakan dua jenis data dalam penelitian ini, yakni data primer dan data sekunder. Data primer dikumpulkan melalui kuesioner. Data sekunder diperoleh dari studi pustaka dan telaah literatur yang terkait baik melalui buku teks, jurnaljurnal ilmiah, serta publikasi lain yang terkait.

\section{Metode Analisis Data}

Untuk menganalisis data dalam penelitian ini digunakan analisis regresi sederhana (simple linier regression) untuk mengetahui penerapan metode pembelajaran kooperatif berbasis kasus terhadap efektifitas pembelajaran mahasiswa akuntansi Universitas Kristen Maranatha.

Model persamaan untuk penelitian ini adalah sebagai berikut:

$$
\mathbf{Y}=\boldsymbol{\beta} 0+\boldsymbol{\beta} 1 \mathbf{X}+\varepsilon
$$

\section{Keterangan:}

$\mathrm{Y}$ : efektifitas pembelajaran mahasiswa

$$
\text { akuntansi }
$$

$\beta 0$ : koefisien intercept (konstanta) yaitu nilai Y jika nilai seluruh variabel lain adalah nol.

$\beta 1$ : koefisien regresi
$\mathrm{X}$ : penerapan metode pembelajaran kooperatif berbasis pembelajaran komperatif berbasis kasus e: error

\section{Hasil Penelitian dan Pembahasan}

\section{Uji Validitas}

Penentuan valid tidaknya item pernyataan menggunakan batas koefisien korelasi terkecil sebesar 0,3 (Sugiyono, 2011) sehingga item yang memiliki koefisien korelasi kurang dari 0,3 dinyatakan tidak valid. Hasil uji tingkat validitas butir pernyataan disajikan dalam tabel berikut:

Tabel 2

Hasil Uji Validitas Variabel Metode Pembelajaran Kooperatif Berbasis Kasus

\begin{tabular}{|c|c|c|}
\hline No & Indeks validitas & Keterangan \\
\hline 1 & 0,612 & valid \\
\hline 2 & 0,450 & valid \\
\hline 3 & 0,561 & valid \\
\hline 4 & 0,599 & valid \\
\hline 5 & 0,559 & valid \\
\hline 6 & 0,501 & valid \\
\hline 7 & 0,601 & valid \\
\hline 8 & 0,659 & valid \\
\hline 9 & 0,588 & valid \\
\hline 10 & 0,428 & valid \\
\hline 11 & 0,480 & valid \\
\hline 12 & 0,654 & valid \\
\hline 13 & 0,592 & valid \\
\hline 14 & 0,751 & valid \\
\hline 15 & 0,701 & valid \\
\hline 16 & 0,648 & valid \\
\hline 17 & 0,584 & valid \\
\hline 18 & 0,569 & valid \\
\hline 19 & 0,470 & valid \\
\hline 20 & 0,586 & valid \\
\hline 21 & 0,570 & valid \\
\hline 22 & 0,553 & valid \\
\hline 23 & 0,588 & valid \\
\hline 24 & 0,617 & valid \\
\hline 25 & 0,651 & valid \\
\hline 26 & 0,603 & valid \\
\hline
\end{tabular}
(X)

Hasil yang diperoleh seperti terlihat pada tabel di atas, memperlihatkan bahwa nilai korelasi (r) untuk Variabel Metode Pembelajaran Kooperatif Berbasis Kasus (X) berada di atas 0,3 maka semua item valid.

Tabel 3

Hasil Uji Validitas Variabel Efektifitas Pembelajaran (Y)

\begin{tabular}{|c|c|c|}
\hline No & Indeks Validitas & Keterangan \\
\hline 1 & 0,731 & valid \\
\hline 2 & 0,747 & valid \\
\hline 3 & 0,621 & valid \\
\hline 4 & 0,665 & valid \\
\hline 5 & 0,550 & valid \\
\hline 6 & 0,703 & valid \\
\hline 7 & 0,661 & valid \\
\hline 8 & 0,560 & valid \\
\hline 9 & 0,621 & valid \\
\hline
\end{tabular}


Hasil yang diperoleh seperti terlihat pada tabel di atas, memperlihatkan bahwa nilai korelasi (r) untuk Variabel Efektifitas Pembelajaran (Y) berada di atas 0,3 maka semua item valid.

\section{Uji Reliabilitas}

Berdasarkan hasil pengolahan diperoleh data sebagai berikut:

Tabel 4

\section{Hasil Uji Reliabilitas Instrumen Penelitian}

\begin{tabular}{|l|c|c|}
\hline \multicolumn{1}{|c|}{ Jumlah butir pertanyaan } & Koefisien reliabilitas & Keterangan \\
\hline Metode pembelajaran $(X) \rightarrow 26$ & 0,922 & Reliabel \\
\hline Efektivitas pembelajaran $(Y) \rightarrow 9$ & 0,827 & Reliabel \\
\hline
\end{tabular}

Hasil perhitungan nilai reliabilitas pada tabel di atas memperlihatkan bahwa untuk variabel Metode Pembelajaran $(\mathrm{X})$ diperoleh nilai reliabilitas sebesar 0,922, untuk variabel Efektifitas Pembelajaran (Y) diperoleh nilai reliabilitas sebesar 0,827 . Terlihat bahwa masing masing variabel memiliki nilai koefisien reliabilitas $>0,60$ sehingga dapat disimpulkan bahwa semua item dari setiap variabel $\mathrm{X}$ dan Y adalah reliabel dan dapat diuji lebih lanjut.

\section{Gambaran Deskriptif Penerapan Metode Pembelajaran Kooperatif Berbasis Kasus}

Berikut ini disajikan tabel dan uraian yang menggambarkan tanggapan responden dari 100 mahasiswa akuntansi yang menjadi sampel penelitian berkaitan dengan penerapan metode pembelajaran kooperatif berbasis kasus.

Tabel 5

Penerapan Metode Pembelajaran Kooperatif Berbasis Kasus

\begin{tabular}{|c|c|c|c|c|c|c|c|c|}
\hline \multirow{2}{*}{ No } & \multirow{2}{*}{ Pertanyaan } & \multicolumn{5}{|c|}{ Jawaban } & \multirow{2}{*}{ Total } & \multirow{2}{*}{ Skor } \\
\hline & & 1 & 2 & 3 & 4 & 5 & & \\
\hline \multicolumn{9}{|c|}{ Pembelajaran Kooperatif } \\
\hline 1 & $\begin{array}{l}\text { Dosen memberikan tugas kelompok } \\
\text { selama proses perkuliahan }\end{array}$ & 2 & 4 & 16 & 49 & 29 & 100 & 399 \\
\hline 2 & \begin{tabular}{|l|} 
Adanya pembagian tugas dalam kelompok \\
yang sesuai dengan tujuan kelompok
\end{tabular} & 1 & 5 & 18 & 51 & 25 & 100 & 394 \\
\hline 3 & $\begin{array}{l}\text { Setiap kelompok diberikan kesempatan } \\
\text { untuk bertemu muka dan berdiskusi }\end{array}$ & 0 & 4 & 9 & 48 & 39 & 100 & 422 \\
\hline 4 & \begin{tabular}{|l|} 
Setiap anggota kelompok diberikan \\
kesempatan untuk mengeluarkan pendapat
\end{tabular} & 0 & 0 & 11 & 46 & 43 & 100 & 432 \\
\hline 5 & $\begin{array}{l}\text { Setiap anggota kelompok dapat } \\
\text { menyeles aikan tugasnya }\end{array}$ & 2 & 5 & 15 & 48 & 30 & 100 & 399 \\
\hline 6 & $\begin{array}{l}\text { Tugas kelompok diselesaikan dengan baik } \\
\text { dan tepat waktu }\end{array}$ & 0 & 4 & 10 & 40 & 46 & 100 & 428 \\
\hline 7 & $\begin{array}{l}\text { Saling menghargai keterampilan masing- } \\
\text { masing anggota kelompok }\end{array}$ & 0 & 8 & 10 & 32 & 50 & 100 & 424 \\
\hline 8 & $\begin{array}{l}\text { Menghargai perbedaan pendapat yang } \\
\text { terjadi dalam kelompok }\end{array}$ & 0 & 4 & 10 & 40 & 46 & 100 & 428 \\
\hline 9 & $\begin{array}{l}\text { Saling melengkapi kekurangan masing- } \\
\text { masing anggota kelompok }\end{array}$ & 3 & 6 & 8 & 39 & 44 & 100 & 415 \\
\hline 10 & $\begin{array}{l}\text { Setiap kelompok terdiri dari anggota dengan } \\
\text { beragam latar belakang }\end{array}$ & 0 & 0 & 5 & 39 & 56 & 100 & 451 \\
\hline 11 & $\begin{array}{l}\text { Setiap kelompok terdiri dari gender pria dan } \\
\text { gender wanita }\end{array}$ & 0 & 5 & 16 & 41 & 38 & 100 & 412 \\
\hline 12 & $\begin{array}{l}\text { Metode pembelajaran kooperatif membuat } \\
\text { pembelajaran berpusat pada mahasiswa }\end{array}$ & 1 & 3 & 16 & 47 & 33 & 100 & 408 \\
\hline 13 & $\begin{array}{l}\text { Bahan belajar saya berasal dari hasil } \\
\text { diskusi setiap kelompok }\end{array}$ & 3 & 17 & 28 & 34 & 18 & 100 & 347 \\
\hline 14 & $\begin{array}{l}\text { Diskusi pakar sangat membantu dalam } \\
\text { mengatasi masalah yang belum } \\
\text { terselesaikan pada saat diskusi }\end{array}$ & 0 & 5 & 17 & 46 & 32 & 100 & 405 \\
\hline 15 & Bahan kuliah saya menjadi lebih lengkap & 1 & 5 & 13 & 44 & 37 & 100 & 411 \\
\hline 16 & $\begin{array}{l}\text { Tugas dirangkum dalam sebuah laporan } \\
\text { hasil diskusi kelompok }\end{array}$ & 1 & 9 & 19 & 42 & 29 & 100 & 389 \\
\hline 17 & $\begin{array}{l}\text { Adanya evaluasi proses kelompok setelah } \\
\text { pembelajaran kooperatif }\end{array}$ & 1 & 11 & 20 & 42 & 26 & 100 & 381 \\
\hline 18 & $\begin{array}{l}\text { Sistem penilaian dalam kelompok meliputi } \\
\text { keaktifan, relevansi pembicaraan dan } \\
\text { keterampilan komunikasi }\end{array}$ & 2 & 4 & 11 & 51 & 32 & 100 & 407 \\
\hline Tota & & 17 & 99 & 252 & 779 & 653 & 1800 & 7352 \\
\hline & entase (dalam \%) & $1 \%$ & $6 \%$ & $14 \%$ & $43 \%$ & $36 \%$ & $100 \%$ & \\
\hline
\end{tabular}

\begin{tabular}{|c|c|c|c|c|c|c|c|c|}
\hline \multirow{2}{*}{ No } & \multirow{2}{*}{ Pertanyaan } & \multicolumn{5}{|c|}{ Jawaban } & \multirow{2}{*}{ Total } & \multirow{2}{*}{ Skor } \\
\hline & & 1 & 2 & 3 & 4 & 5 & & \\
\hline \multicolumn{9}{|c|}{ Pembelajaran Berbasis Kasus } \\
\hline 19 & \begin{tabular}{|l|} 
Tugas kasus mengenalkan mahasiswa \\
pada permasalahan yang terjadi pada dunia \\
praktik
\end{tabular} & 0 & 2 & 15 & 43 & 40 & 100 & 421 \\
\hline 20 & \begin{tabular}{|l} 
Pemberian kasus dalam proses \\
pembelajaran membuat mahasiswa \\
mampu memecahkan masalah
\end{tabular} & 0 & 5 & 8 & 47 & 40 & 100 & 422 \\
\hline 21 & $\begin{array}{l}\text { Belajar berbagai kasus membuat } \\
\text { mahasiswa lebih memahami materi }\end{array}$ & 1 & 5 & 10 & 39 & 45 & 100 & 422 \\
\hline 22 & $\begin{array}{l}\begin{array}{l}\text { Pembelajaran berbasis kasus lebih } \\
\text { meringankan mahasiswa dalam mencari } \\
\text { literatur }\end{array} \\
\end{array}$ & 3 & 6 & 22 & 38 & 31 & 100 & 388 \\
\hline 23 & $\begin{array}{l}\text { Tugas berupa kasus diikutkan dalam } \\
\text { penilaian }\end{array}$ & 1 & 3 & 13 & 49 & 34 & 100 & 412 \\
\hline 24 & $\begin{array}{l}\text { Tugas berupa diskusi kasus membuat } \\
\text { mahasiswa mampu menginterpretasikan } \\
\text { masalah }\end{array}$ & 2 & 3 & 10 & 44 & 41 & 100 & 419 \\
\hline 25 & \begin{tabular}{|l|} 
Pembelajaran berbasis kasus bisa \\
diterapkan pada kasus dunia profesional
\end{tabular} & 0 & 4 & 12 & 42 & 42 & 100 & 422 \\
\hline 26 & $\begin{array}{l}\text { Pembelajaran berbasis kasus bermanfaat } \\
\text { untuk membiasakan belajar mandiri }\end{array}$ & 0 & 4 & 5 & 50 & 41 & 100 & 428 \\
\hline Tot & & 7 & 32 & 95 & 352 & 314 & 800 & 3334 \\
\hline & ientase (dalam \%) & $1 \%$ & $4 \%$ & $12 \%$ & $44 \%$ & $39 \%$ & $100 \%$ & \\
\hline TOT & & & & & & & & 10686 \\
\hline
\end{tabular}

Dari skor item diperoleh total skor sebesar 10686. Tanggapan responden diklasifikasikan pada rentang skor sebagai berikut:

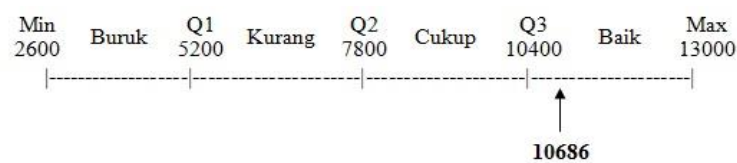

Gambar 2

Interval Skor Metode Pembelajaran Kooperatif Berbasis Kasus

Terlihat secara keseluruhan penerapan metode pembelajaran kooperatif berbasis kasus berada dalam kategori baik. Gambaran penerapan metode pembelajaran kooperatif berbasis kasus telah diterapkan dengan baik dapat dilihat bahwa dosen memberikan tugas kelompok selama proses perkuliahan, adanya pembagian tugas dalam kelompok yang sesuai dengan tujuan kelompok, setiap kelompok diberikan kesempatan untuk bertemu muka dan berdiskusi juga diberikan kesempatan untuk mengeluarkan pendapat. Dalam setiap kelompok terdiri dari anggota dengan beragam latar belakang dan gender. Terjadi saling menghargai keterampilan masing-masing anggota kelompok, menghargai perbedaan pendapat yang terjadi dalam kelompok, dan saling melengkapi kekurangan masing-masing anggota kelompok. Diskusi kelompok, diskusi pakar membuat bahan kuliah menjadi lebih lengkap. Setiap kelompok diberikan tugas kasus yang disesuaikan dengan issue-issue yang up to date dalam dunia praktik. Tugas kasus tersebut dapat membuat mahasiswa mampu memecahkan masalah, bermanfaat untuk membiasakan belajar mandiri, meringankan mahasiswa dalam mencari literatur, mengenal kasus di dunia praktik, dan membuat mahasiswa lebih memahami materi. Sebagai evaluasi ada sistem penilaian yang meliputi tugas yang dirangkum dalam sebuah laporan hasil diskusi kelompok, penilaian 
keaktifan, relevansi pembicaraan, dan keterampilan komunikasi.

\section{Gambaran Deskriptif Efektifitas Pembelajaran}

Berikut ini disajikan tabel dan uraian yang menggambarkan tanggapan responden dari 100 mahasiswa akuntansi yang menjadi sampel penelitian berkaitan dengan efektifitas pembelajaran.

Tabel 6

Efektifitas Pembelajaran

\begin{tabular}{|c|c|c|c|c|c|c|c|c|}
\hline \multirow{2}{*}{ No } & \multirow{2}{*}{ Pertanyaan } & \multicolumn{5}{|c|}{ Jawaban } & \multirow{2}{*}{ Total } & \multirow{2}{*}{ Skor } \\
\hline & & 1 & 2 & 3 & 4 & 5 & & \\
\hline \multicolumn{9}{|c|}{ Etektivitas Pembelajaran Mahasiswa } \\
\hline 1 & $\begin{array}{l}\text { Metode pembelajaran kooperatif berbasis } \\
\text { kasus bermantaat untuk membiasakan } \\
\text { mahasiswa belajar mandiri }\end{array}$ & 0 & 3 & 13 & 46 & 38 & 100 & 419 \\
\hline 2 & $\begin{array}{l}\text { Metode pembelajaran kooperatif berbasis } \\
\text { kasus meningkatkan kemampuan } \\
\text { memecahkan masalah }\end{array}$ & 0 & 3 & 7 & 40 & 50 & 100 & 437 \\
\hline 3 & $\begin{array}{l}\text { Daya ingat terhadap imu yang saya } \\
\text { dapatkan dari metode pembelajaran } \\
\text { kooperatif berbasis kasus lebih tahan lama }\end{array}$ & 1 & 6 & 15 & 44 & 34 & 100 & 404 \\
\hline 4 & $\begin{array}{l}\text { Metode pembelajaran kooperatif berbasis } \\
\text { kasus membuat mahasiswa belajar lebih } \\
\text { mendalam }\end{array}$ & 1 & 2 & 15 & 47 & 35 & 100 & 413 \\
\hline 5 & $\begin{array}{l}\text { Pengetahuan mahasiswa menjadi lebih } \\
\text { luas dibanding dengan model kuliah } \\
\text { konvensional }\end{array}$ & 0 & 1 & 10 & 48 & 41 & 100 & 429 \\
\hline 6 & $\begin{array}{l}\text { Hasil belajar mahasiswa meningkat setelah } \\
\text { penerapan metode pembelajaran kooperaiff } \\
\text { berbasis kasus }\end{array}$ & 0 & 4 & 16 & 55 & 25 & 100 & 401 \\
\hline 7 & $\begin{array}{l}\text { Metode pembelajaran kooperatif berbasis } \\
\text { kasus adalah proses belajar yang } \\
\text { menyenangkan }\end{array}$ & 2 & 5 & 15 & 46 & 32 & 100 & 401 \\
\hline 8 & $\begin{array}{l}\text { Mahasiswa menjadi sadar bahwa belajar } \\
\text { merupakan kebutuhan }\end{array}$ & 1 & 2 & 14 & 36 & 47 & 100 & 426 \\
\hline 9 & $\begin{array}{l}\text { Konsep dan langkah metode pembelajaran } \\
\text { kooperatiff berbasis kasus telah diterapkan } \\
\text { oleh dosen }\end{array}$ & 0 & 1 & 17 & 45 & 37 & 100 & 418 \\
\hline Tote & & 5 & 27 & 122 & 407 & 339 & 900 & 3748 \\
\hline & entase (dalam \%) & $1 \%$ & $3 \%$ & $14 \%$ & $45 \%$ & $38 \%$ & $100 \%$ & \\
\hline
\end{tabular}

Dari skor item diperoleh total skor sebesar 3748. Tanggapan responden diklasifikasikan pada rentang skor sebagai berikut:

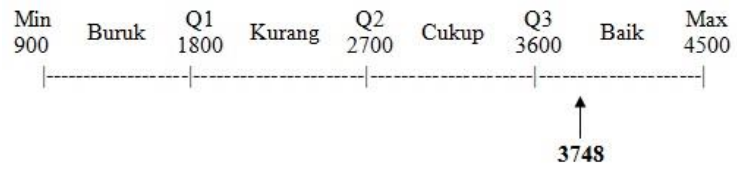

Gambar 3

Interval Skor Efektifitas Pembelajaran
Terlihat secara keseluruhan efektifitas pembelajaran berada dalam kategori baik. Gambaran efektivitas pembelajaran mahasiswa berada dalam kategori baik dapat dilihat dari peningkatan kualitas kemampuan memecahkan masalah karena dengan metode pembelajaran kooperatif berbasis kasus mahasiswa terbiasa belajar mandiri. Peningkatan aktifitas mahasiswa dalam pembelajaran karena metode pembelajaran kooperatif berbasis kasus membuat mahasiswa belajar lebih mendalam dan daya ingat terhadap ilmu yang saya dapatkan dari metode pembelajaran kooperatif berbasis kasus lebih tahan lama. Peningkatan hasil belajar mahasiswa karena pengetahuan mahasiswa menjadi lebih luas dibanding dengan model kuliah konvensional. Adanya respon positif terhadap proses pembelajaran kooperatif berbasis kasus, mahasiswa menganggap metode pembelajaran kooperatif berbasis kasus adalah proses belajar yang menyenangkan sehingga mereka menjadi sadar bahwa belajar merupakan kebutuhan.

\section{Pengujian Hipotesis}

Tabel 7

Koefisien Regresi dan Uji Signifikansi Coefficients $^{\mathrm{a}}$

\begin{tabular}{|l|r|r|r|r|r|}
\hline Model & \multicolumn{2}{|c|}{$\begin{array}{l}\text { Unstandardi } \\
\text { zed } \\
\text { Coefficients }\end{array}$} & $\begin{array}{c}\text { Standardiz } \\
\text { ed } \\
\text { Coefficien } \\
\text { ts }\end{array}$ & t & Sig \\
& B & $\begin{array}{c}\text { Std. } \\
\text { Error }\end{array}$ & Beta & \\
\hline (Consta &, 80 &, 267 & & 3,011 &, 00 \\
nt) & 5 & & & 12,65 &, 00 \\
X &, 81 &, 065 &, 788 & 2 & 0 \\
\hline
\end{tabular}

a. Dependent Variable: Y

Hasil perhitungan koefisien regresi berdasarkan data penelitian yang diperoleh dapat ditulis dalam persamaan regresi taksiran sebagai berikut:

$$
\mathbf{Y}=\mathbf{0 , 8 0 5}+\mathbf{0 , 8 1 7 X}+\varepsilon 1
$$

Dari persamaan di atas maka dapat dijelaskan bahwa penerapan metode pembelajaran kooperatif berbasis kasus berpengaruh secara positif dan signifikan terhadap efektifitas pembelajaran mahasiswa yang terlihat dari nilai koefisien regresi variabel $\mathrm{X}$ diperoleh bertanda positif sebesar 0,817 dengan tingkat signifikan 0,000. Jadi dapat dijelaskan bahwa pengaruh penerapan metode pembelajaran kooperatif berbasis kasus terhadap efektifitas pembelajaran mahasiswa berbanding lurus (berpengaruh secara positif) yang terlihat dari koefisien regresi yang diperoleh positif. 
Uji Normalitas

Hasil perhitungan uji normalitas menggunakan Kolmogorov-Smirnov Test diberikan pada tabel berikut:

Tabel 8

Hasil Uji Normalitas

One-Sample Kolmogorov-Smirnov Test

\begin{tabular}{|ll|r|}
\hline & & $\begin{array}{r}\text { Unstandardized } \\
\text { Residual }\end{array}$ \\
\hline $\mathrm{N}$ & Mean & $\mathbf{1 0 0}$ \\
Normal & Std. & $\mathbf{0 E - 7}$ \\
Parameters $^{\text {a,b }}$ & Deviation &, 32108142 \\
Most Extreme & Absolute &, 073 \\
Differences & Positive &, 073 \\
& Negative & $\mathbf{- , 0 6 5}$ \\
Kolmogorov-Smirnov Z &, 733 \\
Asymp. Sig. (2-tailed) &, 655 \\
\hline
\end{tabular}

a. Test distribution is Normal.

b. Calculated from data.

Hasil yang diperoleh berdasarkan nilai signifikansi uji Kolmogorov-Smirnov Test pada tabel di atas dapat dilihat bahwa nilai probabilitas (sig.) untuk model persamaan penelitian ini diperoleh sebesar 0,655. Nilai probabilitas uji normalitas untuk masing-masing model regresi lebih besar dari 5\% atau 0,05 menunjukkan bahwa hasil taksiran model regresi mengikuti distribusi normal.

\section{Uji Heterokedastisitas}

Berdasarkan output Scatterplot di bawah ini dapat dilihat bahwa titik-titik data menyebar, tidak berkumpul di satu titik saja. Penyebaran titik-titik data tidak berpola sehingga dapat disimpulkan bahwa tidak terjadi masalah heterokedastisitas.

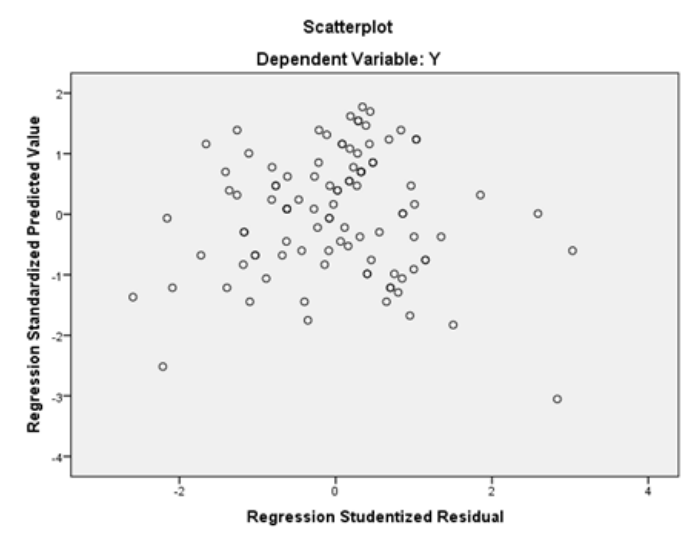

Gambar 4

Hasil Uji Heterokedastisitas

\section{Pembahasan}

Hipotesis penelitian ini adalah "Penerapan metode pembelajaran kooperatif berbasis kasus berpengaruh terhadap efektivitas pembelajaran mahasiswa". Dari hasil data statistik yang diolah melalui uji signifikansi diperoleh hasil $\mathrm{T}$ hitung sebesar 12,652 lebih besar dibandingkan dengan $\mathrm{T}$ tabel sebesar 1,984 dengan tingkat kekeliruan $5 \%(\alpha=0,05)$, yang berarti bahwa $\mathrm{H}_{0}$ yang menyatakan bahwa penerapan metode pembelajaran kooperatif berbasis kasus tidak berpengaruh terhadap efektivitas pembelajaran mahasiswa, ditolak. Selain itu juga dapat terlihat bahwa koefisien regresi penerapan metode pembelajaran kooperatif berbasis kasus menunjukkan arah yang positif sebesar 0,817 dengan nilai signifikan 0,000 lebih kecil dari 0,05. Sedangkan dari perhitungan koefisien determinan diperoleh nilai R2 sebesar 0,620 yang memiliki arti bahwa 62\% efektivitas pembelajaran mahasiswa dipengaruhi oleh metode pembelajaran kooperatif berbasis kasus, sisanya dipengaruhi oleh faktor lain.

Berdasarkan hasil pengujian statistik yang telah dilakukan, dapat dianalisis bahwa Program Studi Akuntansi Universitas Kristen Maranatha telah menerapkan metode pembelajaran kooperatif berbasis kasus dengan baik sehingga metode pembelajaran tersebut memberikan pengaruh positif terhadap efektivitas pembelajaran mahasiswa. Adanya indikasi bahwa metode pembelajaran kooperatif berbasis kasus telah diterapkan dengan baik terlihat dari penerapan belajar kelompok hampir di setiap mata kuliah, kelompok tersebut terdiri dari kelompok kecil mahasiswa yang heterogen, kelompok-kelompok tersebut diberikan soal-soal berbasis kasus yang diselesaikan dengan bekerja sama dan saling membantu satu sama lain.

Penerapan metode pembelajaran kooperatif sudah dilakukan dengan baik, terlihat pada dimensi pembelajaran kooperatif sebagian besar responden memberikan penilaian pada skor 4 (43\%) yang artinya telah diterapkan metode pembelajaran kooperatif dengan pemilihan anggota kelompok yang heterogen terdiri dari latar belakang, keterampilan yang berbeda dan gender yang berbeda, terwujudnya tingkat saling ketergantungan secara positif dengan cara memberikan tugas kelompok selama proses perkuliahan dan ada pembagian tugas dalam kelompok yang sesuai dengan tujuan kelompok bukan tujuan pribadi, sehingga saling ketergantungan secara positif dapat terwujud. Dalam pembelajaran kelompok terjadi interaksi langsung/ tatap muka untuk berdiskusi, masing-masing anggota kelompok diberikan kesempatan untuk mengeluarkan pendapat. Setiap individu dan kelompok mempunyai tanggungjawab dalam menyelesaikan tugas dengan baik dan tepat waktu. Di dalam kelompok terjadi saling menghargai perbedaan pendapat, menghargai keterampilan setiap individu dan saling melengkapi 
kekurangan masing-masing anggota kelompok. Dalam proses pembelajaran kooperatif, pembelajaran berpusat pada mahasiswa sehingga hasil diskusi kelompok dan diskusi pakar dapat menjadi bahan pelajaran yang sangat bermanfaat. Dilakukan evaluasi dalam pembelajaran kelompok dengan sistem penilaian kelompok meliputi keaktifan, keterampilan komunikasi dan membuat laporan hasil diskusi kelompok.

Penerapan metode pembelajaran berbasis kasus juga sudah dilakukan dengan baik, terlihat pada dimensi pembelajaran berbasis kasus sebagian besar responden memberikan penilaian pada skor 4 (44\%) yang artinya pemberian tugas kasus dalam proses pembelajaran sudah dilakukan, dengan pemberian tugas kasus meningkatkan kemampuan mahasiswa dalam memecahkan masalah karena pembelajaran berbasis kasus mengenalkan mahasiswa pada permasalahan yang terjadi di dunia praktik. Dengan belajar berbagai kasus dapat meningkatkan tingkat pemahaman materi dan meringankan mahasiswa dalam mencari literatur serta meningkatkan kemampuan mahasiswa dalam menginterpretasikan suatu masalah. Pembelajaran berbasis kasus memberikan kontribusi yang bermanfaat untuk membiasakan mahasiswa belajar mandiri dan dapat diterapkan dalam kasus dunia praktik.

Dari paparan di atas, dapat disimpulkan bahwa penerapan metode pembelajaran kooperatif berbasis kasus yang diterapkan pada mahasiswa Program Studi Akuntansi Universitas Kristen Maranatha sudah dilakukan dengan baik sehingga dapat meningkatkan efektivitas pembelajaran mahasiswa. Efektivitas pembelajaran mahasiswa menjadi lebih baik dilihat dari sebagian besar responden memberikan penilaian pada skor $4(45 \%)$ artinya terjadi peningkatan kemampuan memecahkan masalah, peningkatan aktifitas mahasiswa dalam pembelajaran, peningkatan hasil belajar mahasiswa, dan respon positif terhadap metode pembelajaran kooperatif berbasis kasus.

Hasil penelitian ini mendukung penelitian yang dilakukan oleh Siti Mutmainah (2008), Rita Endriani dan Elda Nazriati (2009), I Nyoman Suardana (2015).

\section{Simpulan dan Saran}

\section{Simpulan}

Dari hasil penelitian mengenai "Penerapan Metode Pembelajaran Kooperatif Berbasis Kasus Terhadap Efektivitas Pembelajaran Mahasiswa Akuntansi Universitas Kristen Maranatha" dapat disimpulkan bahwa penerapan metode pembelajaran kooperatif berbasis kasus memberikan pengaruh positif terhadap efektivitas pembelajaran mahasiswa akuntansi Universitas Kristen Maranatha. Metode pembelajaran kooperatif berbasis kasus sudah diterapkan dengan baik di Program Studi Akuntansi Universitas Kristen Maranatha.

\section{Saran}

Beberapa saran yang penulis ajukan berkaitan dengan hasil penelitian ini adalah:

1. Dosen lebih banyak memberikan arahan kepada mahasiswa saat diskusi kelompok.

2. Lebih ditingkatkan melakukan evaluasi proses belajar kelompok supaya dapat menerima masukan-masukan dari mahasiswa guna memperbaiki proses pembelajaran.

3. Bagi peneliti berikutnya disarankan agar dalam penelitian selanjutnya dapat menggunakan responden yang berbeda dan responden yang lebih banyak agar hasilnya lebih representatif, selain itu juga disarankan untuk penambahan variabel.

\section{Daftar Pustaka}

Afiatin, Tina. (2009). Pembelajaran Berbasis StudentCentered Learning. Yogyakarta: BPFE.

Endriani, Rita dan Elda Nazriati. (2009). Pendapat Mahasiswa Terhadap Implementasi Kurikulum Berbasis Kompetensi (KBK) dengan Problem Based Learning (PBL) di Fakultas Kedokteran Riau Pekanbaru. E-Journal Universitas Riau JIK. Jilid 3, No. 1. Hal. 49-58.

Handoko, Hani. (2005). Metode Kasus dalam Pengajaran (Manajemen). Makalah Lokakarya Peningkatan Kemampuan Penyusunan dan Penerapan Kasus untuk Pengajaran. Semarang 23 November 2005.

Mutmainah, Siti. (2008). Pengaruh Penerapan Metode Pembelajaran Kooperatif Berbasis Kasus Yang Berpusat Pada Mahasiswa Terhadap Efektivitas Pembelajaran Akuntansi Keperilakuan. Simposium Nasional Akuntansi XI. Pontianak.

Muhidin, Samba Ali. (2009). Pembelajaran Kooperatif Untuk Membangun Pengetahuan. Yogyakarta: BPFE.

Phipps, Maurice et al. (2001). University Students' Perception of CooperativeLearning:Implications for Administrators and Instructors. The Journal of Experiential Education. Spring, Vol. 24 No. 1, p.14-21.

Potthast, Margaret J. (1999). Outcomes of Using Small-Group Cooperative Learning Experiences in Introductory Statistics Courses. College Student Journal. March Vol. 22, Issue 1.

Slavin, Robert E. (2008). Cooperatif Learning Teori, Riset, dan Praktek. Terjemahan Nurulita Yusron. Bandung: Nusa Media. 
Suardana, I Nyoman. (2006). Penerapan Strategi Pembelajaran Berbasis Masalah Dengan Pendekatan Kooperatif Berbantuan Modul Untuk Meningkatkan Kualitas Proses Dan Hasil Belajar Mahasiswa Pada Perkuliahan Kimia Fisika I. Jurnal Pendidikan Dan Pengajaran IKIP Negeri Singaraja. Vol. 39 No. 4. ISSN 0215-8250.

Sugiyono. (2011). Statistika Untuk Penelitian. Bandung: Alfabeta.

www.kompas.com.17/01/2006. Pedagogi

Pasca-UU Guru dan Dosen: oleh Andreas Yumarma 